\title{
The Influence of Meaningful Work and Organizational Citizenship Behavior on Job Performance of Employees in PT X Mojokerto
}

\section{Dian Safitri", and Diyah Sulistiyorini}

Psychology, Universitas Negeri Malang, Malang

\section{ORCID}

Dian Safitri; https://orcid.org/0000-0001-6057-0265

Corresponding Author: Dian

Safitri; email:

dian.safitri.1708116@

students.um.ac.id

Dates

Published 28 January 2022

Publishing services provided by

Knowledge E

(c) authors. This article is

distributed under the terms of

the Creative Commons

Attribution License, which

permits unrestricted use and

redistribution provided that the

original author and source are credited.

Selection and Peer-review under the responsibility of the ICoPsy Conference Committee.

\section{G OPEN ACCESS}

\begin{abstract}
Level of performance in a particular job is crucial because it can make a major contribution to the sustainability of the company. The purpose of this research was to examine how meaningful work and organizational citizenship behavior influence employee performance. This research used a quantitative approach and data were collected using the Individual Work Performance Questionnaire, Organizational Citizenship Behavior, and Work and Meaning Inventory. The sample of this research included 86 employees who worked at PT. $X$ in Mojokerto who were recruited using simple random sampling. The analysis techniques used in this research were the instrument test, descriptive test and classical assumption test. The results revealed that meaningful work had no significant effect on performance $(p=0.77>0.05)$. However, the results showed that organizational citizenship behavior had a significant influence on performance $(p<0.05)$. The findings on the simultaneous effect of meaningful work and organizational citizenship behavior on performance revealed significant results ( $p$ $<0.05$ ). It is recommended that future studies examine other variables that may play a role in improving performance, such as job satisfaction and leadership.
\end{abstract}

Keywords: job performance, organizational citizenship behavior, meaningful work

\section{Introduction}

Every organization was created to achieve certain goals. The organization is a social unit that seeks to achieve certain goals and the nature of the organization doesn't pursue goals [1]. The era globalization, Indonesia is one of the countries that has been carried out a Free Trade Agreement (FTA), such as a free trade agreement made between a country and a free country due to unavoidable liberalization. Industries in Indonesia will face competition due to the global economic crisis [2]. In order for an industry to be able to survive in the economic crisis, it is necessary to increase competitiveness. Policies to increase competitiveness can be carried out through sharpening employee performance or performance [3]. 
Bernardin \& Russell defines performance as the results obtained from certain jobs during a specified period of time so they can contribute to the company [4]. High performance allows an organization to survive in global competition right now. Therefore, it is not surprising that performance is the "center of gravity" because it is a manifestation of organizational democracy and an important factor in the life of organizations and companies [5]. However, not all employees can show good performance. One of the inhibiting factors is excessive workload and pressure at work. It has a negative impact on employee motivation at work because employees work of the element of compulsion [6]. Therefore, it is important for companies or organizations to provide an understanding related to the importance of work orientation and the meaningful work [7]. Hick \& Routledge said that the meaningful work can encourage someone to do their job voluntarily [8].

In addition to meaningful work, it is known that there are other variables that significantly job performance, such as Organizational Citizenship Behavior or referred to as organizational citizenship behavior. Organizational Citizenship Behavior is related to study of what is individuals do at an organization and how their behavior affects organizational job performance [19]. It was known that the meaningful work and organizational citizenship behavior have two variables that are close to each other. It because of individuals who are engaged at meaningful work have characteristics that play an important role for every organization, such as employee involvement at Organizational Citizenship Behavior is very large. This is in line with the opinion of Devivere which said that people who are involved at meaningful work appear to have characteristics desired by the organization, such as greater involvement in organizational citizenship behavior [9].

In addition, the results of research Selamat, et al said that there is a significant relationship between meaningful work and Organizational Citizenship Behavior with a percentage of $74 \%$ which indicates that meaningful work and Organizational Citizenship Behavior are vital factors and can contribute to a company or organization [10]. Furthermore, the relationship between Organizational Citizenship Behavior and employee performance was conveyed by the empirical findings of Lestari \& Ghaby which explain that Organizational Citizenship Behavior has a positive effect on employee performance [11] . Total of percentages of success reached $89.6 \%$. This figure shows that $89.65 \%$ of employee satisfaction and performance variables are influenced by Organizational Citizenship Behavior. Thus, it was said that the higher of the Organizational Citizenship Behavior can be the higher the job satisfaction which can ultimately have an impact on 
employee job performance. Based on the explanation described above, it can be concluded that Meaningful work and Organizational Citizenship Behavior together have a crucial role in improving employee job performance. The distinguishes between current research and research conducted by Lestari \& Gabby [11] is the dimensions used, this study adds a new dimension developed by Koopmans [12] like the counterproductive work behavior dimension or behavior can detrimental to the organization. It because of employees whos think their work is meaningful or valuable will have high morale so it ultimately has an impact on good job performance [13].

This research was conducted in PT $X$ Mojokerto. Based on the results of the researcher's interview with the head of Human Resources Development (HRD), the company have various problems related to employee performance such as decreased performance caused by lack of cooperation and collaboration among employees, personal problems of employees who are brought into work which have an impact on low morale, work targets that haven't been achieved, employees only work according to the job description and tend to wait for orders from superiors to do work that exceeds normal hours and there are employees who don't comply with regulations such as being late for work.

Based on various human resource problems that ultimately have an impact on the low job performance of PT X's employees. Researchers are interested in conducting research related to performance. In addition, no previous research has examined the concept of meaningful work and organizational citizenship behavior which simultaneously (simultaneously) affects performance in a research concept framework. Seeing the importance of the meaningful work and organizational citizenship behavior on the level of performance at an organization or company as well as the performance problems of PT X's employees, the authors are encouraged to conduct a study entitled "The Influence of Meaningful Work and Organizational Citizenship Behavior on Performance of employees in PT X Mojokerto".

\section{Literature Review}

Job performance can be defined as the level of employee skills in doing the jobs that are part of the job description [14]. Meanwhile, according to Koopmans define a performance as a pattern of behavior and actions of employees in accordance with organizational goals [12]. The performance at question emphasizes more on the behavior patterns and actions of employees than the results of the behavior itself, such as behavior controlled by the individual [12]. Job performance have four dimensions such as Task Performance, 
Contextual Performance, Adaptive Performance and Counterproductive Work Behaviors [12].

Yoeman et al. define the meaning of work is not only limited to work on valuable or valuable for individuals or employees but has a significant and positive attachment to the employee's personality through the experience, suitability, balance and totality of employees in doing work [15]. Meanwhile, according to Steger \& Dik define the meaningful work as work that has meaning, which refers to a person's perspective broadly related to the work done. In addition, the meaningful work is the ultimate goal in this work [16]. There are three dimensions of the meaningful work such as Positive Meaning, Meaning Making Through Work and Greater Good Motivation [17].

Organ defines that organizational citizenship behavior as individual behavior was voluntary, such as individual behavior that is informally carried out without coercion and is not related to the organization's formal reward system but overall can contribute positively to organizational effectiveness [18]. Organizational citizenship behavior is the behavior of individuals or individuals who are free to do or choose (not an obligation). This behavior is not part of the formal requirements of the job, but can improve the effective functioning of the organization [19]. This behavior was referred to as extrarole behavior, which refers to behavior outside of an employee's normal job duties that exceeds the call of duty or exceeds the requirements of his work role [20]. There are five aspects of organizational citizenship behavior such as Altruism, Sportsmanship, Conscientiousness, Courtesy and Civic virtue [21].

The meaningful work is closely related to the psychological condition of employees. Employees who work with meaning can contribute to the quality of performance in an organization [8]. The results of the research conducted by Tong regarding the relationship between the meaningful work and the job performance of nurses [13]. The results of the study explained that there were a significant positive relationship between the meaningful work and organizational citizenship behavior $(p<.001)$. Descriptive analysis shows that most of the respondents are women (74.6\%). The majority of respondents were between $31^{\text {th }}$ years old and $40^{\text {th }}$ years old $(40.7 \%)$. Most of the respondents are Malay (82.3\%), have a bachelor's degree.

Devivere argues that the meaningful work and organizational citizenship behavior are two variables that were related to each other. It was said to be related because people who are involved in meaningful work have characteristics that are highly desired by every organization, such as their involvement in organizational citizenship behavior is very large [9]. Based on the research results of Selamat et al, it has known that there is a significant relationship $(p<.001)$ between the meaningful work and organizational 
citizenship behavior with a percentage of $74 \%$ [10]. It shows that the meaningful work and organizational citizenship behavior is an important factor in contributing to a company or organization. The results of the research by Abrar \& Isyanto explained that the constant value were found to be 17.338 and the coefficient value of the organizational citizenship behavior variable was .294 and had a significant value below .05 [22]. So, if the OCB variable increases, the performance variable will be increase by .294 . The purpose of this research are to provide a good understanding of the meaningful work and organizational citizenship behavior in influencing employee performance and to find out together the meaning of work and organizational citizenship behavior influence on performance.

\section{Method}

\subsection{Research Subject}

This research using a quantitative research approach with multiple linear regression analysis method because the independent variable consists of more than one. The population of this research are employees who work at PT $X$ that have worked at least 3 months with a total population of 600 em-ployees. The sampling method (sampling technique) used is the probability sampling method using simple random sampling technique, the sampling procedure used is by lottery (lottery), where all elements or members of the population are numbered sequentially from 1 to the total population $(\mathrm{N})$. , then the numbers are randomized and take as many samples as needed are selected. This research was known that the number of $N$ is 600 employees and the required sample is 86 (slovin formula).

\subsection{Research Instrument}

This research using three instrument variables, such as meaningful work scale, organizational citizenship behavior, and job performance. To measure the meaningful work, the researcher adapted the Work and Meaning Inventory (WAMI) instrument developed by Steger et al., consist of 10 items from three subscales, like positive meaning (4 items), meaning making through work ( 3 items), and greater good motivation (3 items) [17]. Reliability was calculated using Cronbach's Alpha with a reliability coefficient of 0.926 .

To measure performance variables, researchers used the Individual Work Performance Questionnaire (IWPQ) instrument developed by Koopmans [12] and has been 
TABLE 1: Results of Reliability Test Instrument.

Variable
Meaningful Work
Organizational Citizenship Behavior
Employee Job Performance

Items
10
19
18

Cronbach
Alpha
.926
.879
.923

Desc.

Reliable

Reliable

Reliable

adapted and translated into Indonesian by [23], consist of 18 items, like 5 items for the task scale performance, 8 items for contextual performance and 5 items for counterproductive work behavior. Reliability was calculated using Cronbach's Alpha with a reliability coefficient of 0.879. Meanwhile, to measure the organizational citizenship behavior variable developed by Organ [18], the researcher adapted the instrument developed by Habeeb [24] which consisted of 19 items from five scales, such as altruism (4 items), sportsmanship ( 5 items), conscientiousness ( 3 items), courtesy ( 3 items), and civic virtue (4 items). Reliability is calculated using Cronbach's Alpha with a reliability coefficient of $0,0,923$.

\subsection{Data Analysis}

The data analysis used is descriptive analysis. Hypothesis testing on this research using multiple linear regression analysis methods with a significance value of $p<.05$. If the $p<$ .05 then there are relationship between the three variables and if the $p>.05$ then there is no relationship between the three variables. Descriptive analysis was conducted with the aim of knowing the big picture of the effect of meaningful work and organizational citizenship behavior on job performance of employees working at PT X Mojokerto. Meanwhile, product moment correlation analysis was conducted to determine whether the meaningful work, organizational citizenship behavior and job performance had a significant relationship and the amount of contribution between meaningful work and organizational citizenship behavior on the job performance of employees working at PT $\mathrm{X}$ Mojokerto.

\section{Result and Discussion}

\subsection{Description and research variable}

The results of calculation descriptive analysis research variable using software statistic are: 
TABLE 2: Results of Calculation Descriptive Analysis Research Variable.

\begin{tabular}{|c|c|c|c|c|c|}
\hline Variable & $\mathbf{N}$ & $\begin{array}{l}\text { Minimum } \\
\text { Value }\end{array}$ & $\begin{array}{l}\text { Maximum } \\
\text { Value }\end{array}$ & Mean & $\begin{array}{l}\text { Std. } \\
\text { Deviation }\end{array}$ \\
\hline Meaningful Work & 86 & 28 & 50 & 39.07 & 5.911 \\
\hline $\begin{array}{l}\text { Organizational Citizenship } \\
\text { Behavior }\end{array}$ & 86 & 35 & 95 & 70.97 & 10.411 \\
\hline Job Performance & 86 & 18 & 88 & 62.87 & 9.182 \\
\hline
\end{tabular}

TABLE 3: Classification of Working Time.

\begin{tabular}{llll}
$\begin{array}{l}\text { Classification } \\
\text { Time }\end{array}$ & of & Working Frequency & Percentage \\
\hline 1 Year & 49 & $57 \%$ \\
$>1$ - 2 Years & 12 & $14 \%$ \\
$>2$ - 3 Years & 18 & $21 \%$ \\
$>3-4$ Years & 4 & $5 \%$ \\
$>4$ - 5 Years & 1 & $1 \%$ \\
$>5$ Years & 2 & $2 \%$ \\
Total & 86 & $100 \%$
\end{tabular}

Based on the calculation table above, using 86 research respondents, it can be seen that the average (mean) total score of meaningful work is 39.07 (10 items). The lowest score is 28 and the highest score is 50 with a standard deviation score of 5.911. Furthermore, the average (mean) total score of the organizational citizenship behavior variable is 70.97 (19 items). The lowest value on the organizational citizenship behavior variable is 35 and the highest value is 95 , for a standard deviation score of 10.411. As for the variable job performance, the average (mean) total score is 62.87 (18 items). The lowest value on the Job Performance variable is 18 and the highest value is 88 , while the standard deviation score is 9.182 .

Based on the results of the classification carried out by researchers, it can be seen from the 86 employees who were used as research samples, the percentage of employees who have worked for less than one year is $57 \%$, worked more than one to two years as much as $14 \%$, worked more than two years. Up to three years as many as $21 \%$, working years of more than three to four years as much as $5 \%$, working years of more than four to five years as much as $1 \%$, and those who have worked more than five years as many as $2 \%$.

\subsection{Hypothesis Test}

Table of calculation the hypothesis test of meaningful work variables, organizational citizenship behavior and job performance. 
TABLE 4: Results of Partial Hypothesis Test (t-test).

\begin{tabular}{|l|l|l|l|l|l|}
\hline Model & \multicolumn{3}{|c|}{ Unstandardized Coefficients } & $\begin{array}{c}\text { Standardized lt } \\
\text { Coefficients }\end{array}$ & Sig. \\
\hline & B & Std. Error & Beta & \\
\hline (Constant) & 13.102 & 5.717 & & $2.292 \mid .024$ \\
\hline X1 & .038 & .129 & .024 & .293 & .770 \\
\hline X2 & .833 & .085 & .791 & $9.820 / .000$ \\
\hline
\end{tabular}

TABLE 5: Results of Simultaneous Hypothesis Test (F Test).

\begin{tabular}{|l|l|l|l|l|l|}
\hline Model & $\begin{array}{l}\text { Sum } \\
\text { Squares }\end{array}$ & of df & $\begin{array}{l}\text { Mean } \\
\text { Square }\end{array}$ & F & Sig. \\
\hline Regression & $\begin{array}{l}460.498 \\
\text { Residual }\end{array}$ & 2 & 2180.249 & 63.942 & $.000^{b}$ \\
\hline Total & 7190.060 & 83 & 34.097 & & \\
\hline
\end{tabular}

Based on table 4 above, it was known that the meaningful work variable has a value of Sig. of .770 or $>0.05$ which means that $\mathrm{H} 1$ is rejected or there is no significant relationship between the $\mathrm{X} 1$ variable (meaningful work with $\mathrm{Y}$ variable (performance). While the organizational citizenship behavior variable has a Sig value of .000 or $<.05$ which means that $\mathrm{H} 2$ is accepted or there is a significant relationship between the $\mathrm{X} 2$ variable (organizational citizenship behavior) and the $Y$ variable (job performance).

Based on table 5 above, it was known that the variables of meaningful work and Organizational Citizenship Behavior have a value of Sig. of .000 or $<.05$ which means that the hypothesis is accepted or there is a significant relationship between the variables X1 (Meaningful Work) and X2 (Organizational Citizenship Behavior) with the $Y$ variable (Job Performance).

\subsection{Discussion}

\subsubsection{The Results of Meaningful Work to Job Performance Improvement}

Based on the results of hypothesis testing that has been carried out by researchers, it was known that the meaningful work variable has a value of Sig. of .770 or $>.05$ which means that $\mathrm{H} 1$ is rejected or there is no significant relationship between the meaningful work variable and the performance variable. The results of this research in line with Allan's research which reveals that meaningful work is not able to predict employee job performance over time [7]. In this research, there was no significant effect of work because the research sample was limited to those who remained on the list of alumni of the almamater who volunteered to participate this research. Grant also expressed 
the same thing that meaningful work shows a weak relationship with employee job performance appraisals both objectively and subjectively [25].

This research, meaningful work has no effect on job performance at PT X. Based on the findings of the data in the field, many respondents do not understand the positive concepts of meaning, Meaning Making Through Work, and Greater Good Motivation. Many respondents answered neutral. For example, in terms of understanding how work contributes to the meaning of life, $32 \%$ of respondents answered neutrally, found a job that is satisfying, $39 \%$ answered neutrally, viewed work as a contribution to personal growth, 31.4 \% answered neutrally, and found a meaningful career, and I know that my work can make a positive difference in the world $38 \%$ answered neutral.

4.3.2 The Results of Organizational Citizenship Behavior to Job Performance Improvement

Based on the results of hypothesis testing that has been carried out by researchers, it was known that the organizational citizenship behavior variable has a value of Sig. of .000 or $<.05$ which means that $\mathrm{H} 2$ was accepted or there is a significant relationship between organizational citizenship behavior variables and job performance variables. The results of this research were supported by research conducted by Lestari \& Ghaby entitled "The Influence of Organizational Citizenship Behavior on Employee's Job Satisfaction and Job Performance" [11]. The results explained that organizational citizenship behavior has a positive effect on job performance with a coefficient value of .40 and $p<.01$. Total percentages of success reached $89.6 \%$. This figure shows that 89.6 $\%$ of the variables of employee satisfaction and job performance were influenced by organizational citizenship behavior. The higher of organizational citizenship behavior, so the higher of job satisfaction and job performance.

In addition, research conducted by Abrar \& Isyanto explained that a constant value of 17.338 is found and the coefficient value of the organizational citizenship behavior variable is 0.294 and has a significant value below .05 [22]. So, if the Organizational Citizenship Behavior variable increases, the performance variable will increased by .294. Based on the results of the previous research, it can be concluded that the organizational citizenship behavior variable has an effect on performance. Organizational citizenship behavior are behavior that is voluntary, carried out informally without coercion and the hope of getting rewarded, carried out freely outside of the duties and responsibilities of work that contributes well to the company.

These behaviors have been carried out by employees of PT X, so they are able to have a positive impact on the company's performance or job performance. Although this behavior is not formally tied to a particular job and there isn't reward, overall it can 
make a good contribution to the function of the organization effectively and efficiently. There are several factors that affect performance such as individual factors, are the characteristics inherent in the individual like the level of education, commitment and competence possessed Putri \& Hadi [26].

\subsubsection{The Results of Meaningful Work and Organizational Citizenship Behavior to Job Performance Improvement}

The results of the partial statistical test of the relationship between meaningful work and job performance revealed non-significant results, while organizational citizenship behavior showed a significant effect on job performance. These differences indicate that the meaningful work has a weak role in improving performance compared to organizational citizenship behavior. Partially testing the relationship between meaningful work and job performance results on an insignificant effect, considering that the meaningful work has a weak correlation with high counterproductive work behaviors which are indicators of job performance [27]. The weak influence of the meaningful work is an inseparable from the lack of employee understanding related to the importance the meaning of job, so has an impact on the low performance of employees [7].

However, simultaneous testing of the effect of the significance of work and organizational citizenship behavior on job performance revealed positive and significance results with the value of Significance of .000 or $<.05$ which means that the hypothesis is accepted or there is a significance relationship between the variables of meaningful work and organizational citizenship behavior with performance. This indicates a meaningful work and job performance are a crucial factor in encouraging employees to improve their performance [10]. Through joint testing, the weak influence of meaningful work, especially on counter productive work behavior which is part of employee job performance, can be minimized by organizational citizenship behavior which has a dominant influence in improving performance. This study was in line with Hulshof et al. which explains that the meaningful work can play a role in improving employee job performance only when employees first engage on helpful behavior [28]. Furthermore, the relationship between meaningful work and organizational citizenship behavior in improving performance was conveyed by empirical findings by Devivere [9] which argues that meaningful work and organizational citizenship behavior are two variables that were related to each other, which in turn can contribute to employee performance [29]. 


\section{Acknowledge, Funding \& Ethics Policies}

Praise the author thanks to God Almighty who has given grace and gifts so the author can complete this article, the author also expresses many thanks to the supervisors who have provided direction and input in writing the article. In addition, the author would like to thank parents and friends who have given prayers and support to the author. Finally, the author would also like to thank myself for trying my best in completing the writing of the article.

\section{References}

[1] Silviana W, Mubarak A. Pengelolaan pengembangan destinasi pariwisata berkelanjutan pada objek wisata Pantai Carocok Painan. Jurnal Mahasiswa IImu Administrasi Publik (JMIAP). 2020;2(3):48-57. DOI: https://doi.org/10.24036/jmiap.v2i3.131

[2] Ingot SR, Laksani DD. ASEAN-Kanada free trade agreement (FTA): Peluang bagi Indonesia. Buletin IImiah Litbang Perdagangan. 2019;13(1):1-20. https://doi.org/10.30908/bilp.v13i1.316

[3] Oktaviani R, Achsani NA, Damanhuri DS, et al. Pembangunan dan kebijakan ekonomi Indonesia menghadapi tantangan globalisasi. Bandung: IPB Press; 2016.

[4] Bernardin HJ, Russell JEA. Human resource management: An experiential approach. Singapore: McGraw-Hill Education; 2006.

[5] Sinaga OS, Hasibuan A, Priyojadmiko EE, et al. Manajemen kinerja dalam organisasi. Medan: Yayasan Kita Menulis; 2020.

[6] Huey BM, Wickens CD. Workload transition: Implications for individual and team performance. Washington DC: National Academy Press; 1993.

[7] Allan BA, Douglass RP, Duffy RD, McCarty RJ. Meaningful work as a moderator of the relation between work stress and meaning in life. Journal of Career Assessment. 2016;24(3):429-440. https://doi.org/10.1177/1069072715599357

[8] Hick JA, Routledge C. The experience of meaning in life: Classical perspectives, emerging themes, and controversies. New York: Springer Dordrecht Heidelberg; 2013.

[9] Devivere B. Meaningful work: Viktor Frankl's legacy for the 21st century. Cham: Springer International Publishing; 2018.

[10] Selamat N, Nordin N, Fook CY. The power of meaningful work: Extra mile teachers. Journal of the International Society for Teacher Education (JISTE). 2017;21(2):7-14. 
[11] Lestari ER, Ghaby NKF. Pengaruh organizational citizenship behavior (OCB) terhadap kepuasan kerja dan kinerja karyawan. Industria: Jurnal Teknologi Dan Manajemen Agroindustri. 2018;7(2):116-123. https://doi.org/10.21776/ub.industria.2018.007.02.6

[12] Koopmans L. Measuring individual performance. Amsterdam: Vrije Universiteit Amsterdam Press; 2014.

[13] Tong L. Relationship between meaningful work and job performance in nurses. International Journal of Nursing Practice. 2018;24(2):1-6. https://doi.org/10.1111/ijn.12620

[14] Byars LL, Rue LW. Human resource management. $7^{\text {th }}$ ed. Chicago: McGraw-Hill Companies, Inc; 2004.

[15] Yoeman R, Bailey C, Madden A, Thomas M. The Oxford handbook of kebermaknaan kerja. New York: Oxford University Press; 2019.

[16] Steger MF, Dik BJ. Oxford handbook of positive psychology and work. Garcea N, Harrington S, editors. Oxford: Oxford University Press; 2009. Work as meaning: Individual and organizational benefits of engaging; p. 1-23.

[17] Steger MF, Dik BJ, Duffy RD. Measuring meaningful work: The work and meaning inventory (WAMI). Journal of Career Assessment. 2012;20(3):322-337. https://doi.org/10.1177/1069072711436160

[18] Organ DW. Organizational citizenship behavior: The good soldier syndrome. Lexington MA: Lexington Books; 1988.

[19] Robbins SP, Judge TA. Organizational behavior. $17^{\text {th }}$ ed. London: Pearson Education; 2017.

[20] Glinow MA, McShane S. Organizational behavior. $8^{\text {th }}$ ed. New York: McGraw-Hill Education; 2018.

[21] Organ DW, Podsakoff PM, MacKenzie SB. Organizational citizenship behavior: Its nature, antecedents, and consequences. California: SAGE Publications Inc.; 2006.

[22] Abrar, U. I. Pengaruh Organizational Citizenship Behaviour (OCB) terhadap kinerja karyawan (Studi pada pt. urchindize cabang madura). Jurnal Perilaku Dan Strategi Bisnis. 2019;7(2):115. DOI: https://doi.org/10.26486/jpsb.v7i2.868

[23] Widyastuti T, Hidayat R. Adaptation of individual work performance questionnaire (IWPQ) into Bahasa Indonesia. International Journal of Research Studies in Psychology. 2018;7(2):101-112. DOI:10.5861/ijrsp.2018.3020

[24] Habeeb S. A proposed instrument for assessing organizational citizenship behavior in BFSI companies in India. Cogent Business and Management. 2019;6(1):1-20. https://doi.org/10.1080/23311975.2019.1625702 
[25] Grant AM. The significance of task significance: Job performance effects, relational mechanisms, and boundary conditions. Journal of Applied Psychology. 2008;93(1):108-124. https://doi.org/10.1037/0021-9010.93.1.108

[26] Putri RS, Hadi C. Hubungan antara emotional labor dengan kinerja pada divisi operation incoming dan outgoing AIESEC Jawa Timur. Jurnal Psikologi Industri Dan Organisasi; 2019;8:20-28.

[27] Long EC, Christian MS, Aryal R, Mch EC, Moore J. Making a real difference: Insights on counterproductive behavior at work [Image on Internet]. 2017. cited 2021 Nov 6 available at https://www.conehealth.com/app/files/public/10476/3-making-areal-difference-insights-on-counterproductive-behavior-at-work-2018.pdf

[28] Hulshof IL, Demerouti E, Le Blanc PM. Day-level job crafting and service-oriented task performance: The mediating role of meaningful work and work engagement. Career Development International. 2020;25(4):355-371. https://doi.org/10.1108/CDI05-2019-0111

[29] Atatsi EA, Stoffers J, Kil A. Factors affecting employee performance: A systematic literature review. Journal of Advances in Management Research. 2019;16(3):329-351. DOI:10.1108/JAMR-06-2018-0052 